\title{
Embodied Objects: Chūjōhime's Hair Embroideries and the Transformation of the Female Body in Premodern Japan
}

\author{
Carolyn Wargula
}

check for updates

Citation: Wargula, Carolyn. 2021. Embodied Objects: Chūjōhime's Hair Embroideries and the Transformation of the Female Body in Premodern Japan. Religions 12: 773. https:// doi.org/10.3390/rel12090773

Academic Editor: Pascale

F. Engelmajer

Received: 1 July 2021

Accepted: 11 August 2021

Published: 15 September 2021

Publisher's Note: MDPI stays neutral with regard to jurisdictional claims in published maps and institutional affiliations.

Copyright: (C) 2021 by the author. Licensee MDPI, Basel, Switzerland. This article is an open access article distributed under the terms and conditions of the Creative Commons Attribution (CC BY) license (https:/ / creativecommons.org/licenses/by/ $4.0 /)$.
Art Department, Williams College, Williamstown, MA 01267, USA; cjw2@williams.edu

\begin{abstract}
The female body in medieval Japanese Buddhist texts was characterized as unenlightened and inherently polluted. While previous scholarship has shown that female devotees did not simply accept and internalize this exclusionary ideology, we do not fully understand the many creative ways in which women sidestepped the constraints of this discourse. One such method Japanese women used to expand their presence and exhibit their agency was through the creation of hair-embroidered Buddhist images. Women bundled together and stitched their hair into the most sacred parts of the image- the deity's hair or robes and Sanskrit seed-syllables-as a means to accrue merit for themselves or for a loved one. This paper focuses on a set of embroidered Japanese Buddhist images said to incorporate the hair of Chūjōhime (753?CE-781?CE), a legendary aristocratic woman credited with attaining rebirth in Amida's Pure Land. Chūjōhime's hair embroideries served to show that women's bodies could be transformed into miraculous materiality through corporeal devotional practices and served as evidence that women were capable of achieving enlightenment. This paper emphasizes materiality over iconography and practice over doctrine to explore new insights into Buddhist gendered ritual practices and draws together critical themes of materiality and agency in ways that resonate across cultures and time periods.
\end{abstract}

Keywords: gender and religion; pure land Buddhism; textiles; Buddhist art; materiality; premodern Japan

\section{Introduction}

Buddhist discourse in premodern Japan long harbored misogynistic views of the female body. Since the ninth century, the Devadatta chapter of the Lotus Sutra was interpreted as evidence that women can only attain buddhahood (jobutsu 成仏) after their bodies undergo a sexual transformation into a male body (Yoshida 2002; Abé 2015). The Blood Bowl Sutra (ketsubon kyō 血盆経), an apocryphal text that emerged in Japan during the fifteenth century, was also quoted to justify the exclusion of women from sacred spaces. ${ }^{1}$ Images are another medium that played a crucial role in disseminating this discourse. Monks contemplated paintings of decaying female corpses, for instance, to expunge sexual desires and to reinforce the belief in the defiled nature of women's bodies (Kanda 2005). Recent studies of gendered ritual practices have revealed that women actively engaged with canonical doctrines (Ruch 2002; Faure 2003; Meeks 2010; Ambros 2015; Gerhart 2018). They were not passive silent victims but instrumental in shaping or defying beliefs concerning the polluted female body. Art historians, though, are mostly silent on how women used image making as an alternative and unorthodox agential practice to achieve buddhahood. This essay proposes a way to fill this over-looked area by examining the embodied practice of hair embroidery that emerged in the late twelfth-century in Japan as an almost entirely female practice.

Human body parts-be they cremated ashes, blood pricked from the finger or the tongue, or fingernail clippings and teeth scrupulously collected-have been adhered to or put into Buddhist images over the centuries. This action has been interpreted as a method of enlivening or empowering images to make them suitable for veneration. Other scholars have described this as a ritual act to create a karmic connection (kechien 結縁) with the 
divine (Sharf 2011; Brinker 2011). These studies, however, have not taken seriously the role of gender. What is the purpose of inserting so-called "polluted" female bodily matter into Buddhist images? Could this be interpreted as a method of exhibiting female agency? If so, how do we define this agency?

The work of postcolonial feminist theorists such as Saba Mahmood have expanded our ways of interpreting female agency beyond binary terms of resistance and conformity. In her study of the piety movement among women in Egypt, Mahmood argues that agency can be enacted "in the multiple ways in which one inhabits norms" (Mahmood 2004, p. 15) through a series of embodied practices. Similarly, Kelsy C. Burke outlines four approaches to understanding religious women's agency - the "compliant approach," which is most apt for this study, focuses on the ways that women conform to gendered religious teachings and expectations for their own internal reasons (Burke 2012). ${ }^{2}$ This framework of female agency reinstates women as actors, rather than passive victims acted upon by male-centered institutions. When applying Mahmood and Burke's notion of female agency to the study of Buddhist hair embroidery, this embodied practice can be interpreted not as a break from societal norms of premodern Japan but rather an alternative adaption to dominant modes of thought and practice.

To investigate this entangled relationship between image making and female agency, hair embroideries thought to be created by Chūjōhime 中将姫 (753?CE-781?CE) will be the focus of this article. Chūjōhime is a legendary figure who attains Buddhahood without transforming into a male body by gathering lotus threads to make the woven Taima mandara 當麻曼陀羅 and then meditating on the visual form of this image. How Chūjōime, a woman whose life is shrouded in myth and folklore, came to be intertwined with the devotional practice of Buddhist hair embroidery remains unknown, yet her name as maker can be found on the back of dozens of these embodied textiles across Japan. Chūjōhime's hair embroideries were likely displayed to female audiences as visual and material indicators of women's ability to achieve rebirth in the female body and functioned as social agents establishing female corporeal presence in male-dominated spaces.

\section{Women's Bodies and the Problems of Salvation}

The Devadatta chapter of the Lotus Sutra gained wide exposure from the tenth century onward in Japan and offered women a possible avenue for salvation through a female to male sexual transformation. In this sutra, the eight-year-old Dragon Princess offers a jewel to Śakyamuni Buddha (Shaka 釈迦) and, within an instant, transforms from a dragon into a man and enters the undefiled realm of enlightened beings (Yoshida 2002; Abé 2015). Because the Dragon Princess only attains Buddhahood through the form of a man, scholarly monks such as Hōnen 法然 (1133-1212), the founder of the Pure Land school, interpreted this sutra as evidence that the female body was limited by the five obstructions (Kamens 1993, p. 400). The five obstructions, a perennial Buddhist discourse in premodern Japan, articulated the inferior, defiled, and unenlightened state of women as it was believed that they were incapable of transforming into five states of superior beings-Brahma, Indra, King Mara, a Cakravartin King, or a Buddha. ${ }^{3}$ Women, thus, were not considered equal to men and faced immense obstacles on the path towards salvation.

The Blood Bowl Sutra, an apocryphal text popularized in Japan during the fifteenth century, added further physiological impediment to female salvation. This sutra, which originated in China at the end of the twelfth century, discusses the journey of the arhat Mokuren 目連 (Ch. Mulian Sk. Maudgalyāyana) into the fiery hells to rescue his mother. Upon his arrival into hell, Mokuran discovers his mother among a group of women drowning in a pool of blood. The demon guardian notices Mokuren's horrified reaction to the gruesome scene and explains that these women are destined to drink the blood in this pool for all of eternity as retribution for defiling the earth with parturitive and menstrual blood. According to this sutra, women were destined to desecrate and anger the gods due to their inherent physiology. If women's blood touches the earth, it contaminates the earth god and if women wash their blood-stained garments, they pollute water used for 
the Buddha's offerings. ${ }^{4}$ Women required monastic intervention to be saved from their impending destinies in the Blood Hells. Copies of the Blood Bowl Sutra were placed in women's coffins for Sōtō Zen funerary rites as it was believed that this sutra functioned as an amulet to protect their souls (Faure 2003, pp. 76-77). Buddhist priests also performed a salvific ritual to save drowning women in the Blood Pools which involved tossing copies of the Blood Bowl Sutra into a river, an act depicted in seventeenth-century hell paintings such as the Tateyama mandara 立山曼荼羅 (Hirasawa 2013, p. 123).

Blood pollution was also considered a serious threat to the sacrality of holy sites and became another justification for the exclusion of women (nyōnin kekkai 女人結界) in spaces such as Mt. Kōya 高野山, the headquarters of the Shingon school of Buddhism. Women were originally prohibited from entering Mt. Kōya because they were perceived to be sexual temptresses that could prevent celibate monks from maintaining monastic precepts (Ambros 2008, pp. 41-47). The Blood Bowl Sutra, though, promoted an ideology of abjection in which the female body became an object of repulsion, her soteriological limitations defined by her bodily functions. Setsuwa 説話 tales, otherwise known as Buddhist didactic stories, include discussions of women who challenge these double standards by ascending to the top of sacred mountains, yet they are often transformed into stone as punishment for their transgressions (Moerman 2005, pp. 203-8).

Itinerant nuns of Kumano, referred to as Kumano bikuni 熊野比丘尼, preached the Blood Bowl Sutra to a primarily female audience and popularized this text's teachings. Located near the Kii peninsula, Kumano was a popular pilgrimage site that welcomed female believers. Kumano bikuni performed picture recitation rituals along the pilgrimage routes as well as at religious festivals in surrounding temples and shrines to raise funds for temple constructions. These itinerant nuns used a wide array of literary and pictorial sources as tools for their teachings including the Nachi Pilgrimage Mandala (Nachi sankei mandara 那智参詣曼荼羅), the Blood Bowl Sutra, the Blood Bowl Sutra engi (Ketsubon kyō engi 血盆経縁起), and the Origins of Kumano (Kumano no honji 熊野の本地).

The Kumano Heart Visualization and Ten World Mandala (Kumano kanshin jikkai mandara 熊野锥心十界曼荼羅) survives today in considerable numbers and was probably the most well-known tool for proselytization. ${ }^{5}$ This complex mandala depicts numerous female hells including the aforementioned hell for parturition and menstrual blood where women are illustrated drowning in pools of blood, a hell for barren women in which women are forced to dig out bamboo shoots with flimsy candlewicks, and a hell for jealous women where women are half-transformed into snakes. ${ }^{6}$ The Kumano nun's proselytization, no doubt, caused fear and panic among its audience and promoted the belief that women's only escape from these hells came from monastic intervention. As the Buddha explains to Mokuren in the Blood Bowl Sutra, women can only be saved from these hells if they "respect the three treasures of filial piety, call on Mokuren, hold a Blood Pool Liberation service, hold a Blood Pool Feast, read sutras, commission an esoteric ceremony, then, make a boat and float it off" (Takemi 1983, pp. 230-32). ${ }^{7}$

The irony of the Kumano itinerant nuns' teachings has not escaped scholars: although Kumano was one of the few sacred mountains that welcomed women and, as Hagiwara Tatsuo notes, the pilgrimage site enabled a religious discourse "by and for women" to flourish, this site further solidified women's dependence on men (Hagiwara 1983, pp. 38-50). Max Moerman writes, "the liberative qualities of the [Kumano bikuni's] discourse remains questionable. As the headquarters of women who preached to women the terms of their iniquity, the place of women's religious freedom was also, paradoxically, the place of their bondage" (Moerman 2005, p. 231). Through consistent reminders of their inescapable corporeal impurity, female pilgrims were taught that the requirements for achieving salvation were different for women. Pure Land Buddhist priests preached that men could attain rebirth simply by chanting the name of Amida Buddha 阿弥陀 (Sk. Amitābha), but this was not enough to assure women's salvation in the Pure Land; women had biological hindrances that impeded their path towards buddhahood. The popularization of the Blood Bowl Sutra, then, promoted the belief in women's inferior physical nature, reinforced the 
ban of women in Buddhist activities and sites, and required women to depend on monastic institutions for deliverance.

\section{The Emergence of Hair Embroidery}

Although discourses concerning the defilement of the female body were prevalent, these teachings did not stop women from using their own bodies, especially the material of hair in the creation of embroidered Buddhist during the late twelfth century. Strands of their hair were bundled together and stitched onto a plain weave silk ground to form the figure of the Amida Buddha, the symbol of a Sanskrit seed-syllable, or excerpts from important texts in the Pure Land tradition such as the Contemplation Sutra (Kanmuryōjukyō 観無量寿経). The medium of textiles likely appealed to these women because all aspects of cloth-making from dyeing threads to embroidering fabrics was considered an essential female virtue. ${ }^{8}$ There were also important precedents of women making textiles as a devotional act, such as the Tenjukoku shūchō mandara 天寿国紼帳曼荼羅 created by the consort of Prince Shōtoku (574-622) (Pradel 2016).

Hair was considered a worthy female offering in a Buddhist context as it symbolized one's sacrifice of the corporeal body and relinquishment of worldly desires (Ten Grotenhuis 2011). Buddhist texts are rife with examples of enlightened beings employing their bodies as offerings. Jātaka tales, stories of the Buddha's former lives, for instance, discuss examples of bodhisattvas surrendering parts of their bodies in the goriest manner as an act of selflessness on the path towards Buddhahood (Ohnuma 1998; Benn 2007). Because women's long, smooth hair in premodern Japan was fetishized and associated with beauty, sexuality, and fertility, cutting one's long locks and incorporating them into embroideries served as the ultimate sacrifice for women and represented one's renunciation of this world. ${ }^{9}$

Hair embroideries became central to memorialization rituals because the material of hair fulfilled an essential need of mourning due to its durability. The twelfth-century poet, Fujiwara no Tameie 藤原為家 (1198-1275), composed a waka poem in response to an embroidered Buddhist image made with the hair of his deceased daughter. "Even after my tears dry, my heart is filled with sadness to see the black hair of my own child," the color of black in opposition to white, becoming a symbol of her youth, a daughter lost during the prime of her life ${ }^{10}$ The making of hair embroidery was also a deeply personal and intimate act. For instance, Emperor Go-Uda 後宇多天皇 (1267-1324) commissioned a Sanskrit seed-syllable embroidered image for his consort, Yūgimon'in 遊義門院 (1270-1307), on the one-year anniversary of her death. The Clear Mirror (Masukagami 増鏡), an account of the imperial court, describes the emperor himself gathering Yūgimon'in's hair from one of her combs to be used for the image and copying the Lotus Sutra on the back of her letters. ${ }^{11}$ This action transformed the material remains of Yūgimon'in, her hair and handwriting, into sacred objects. The creation of hair embroidery, then, offered posthumous merit to the deceased, especially women, who had countless barriers on the path towards enlightenment. $^{12}$

Among these documents are several records of widows who created embroidered Buddhist images using not the hair of their deceased husbands, but their own. The most well-known example concerns Hōjō Masako 北条政子 (1156-1225), the wife of the eminent founder of the Kamakura warrior government, Minamoto no Yoritomo 源頼朝 (11471199). The Mirror of the East (Azuma kagami 吾妻鏡), a historical chronicle of the Kamakura government, records that on 1200.1.13, Masako held a lavish one-year memorial service for her husband and provided many offerings including a painting of Śakyamuni Buddha flanked by two attendants (Shaka sanzon 釈迦三尊), six gold-leaf Lotus Sutra scrolls, and five scrolls from the Mahāyāna sutras (daijōkyō 大乗経). ${ }^{13}$ The main object of worship (honzon 本尊) was an embroidery of a Sanskrit seed-syllable incorporating Masako's own hair from when she took the tonsure after Yoritomo's death (Itō 2012). ${ }^{14}$ Widows were expected to cut their hair as a symbolic gesture of renouncing the world. The corporeal materiality of these embroideries may have been considered especially suitable for exhibiting and fulfilling these essential virtues of fidelity and chastity among widows. 
Taking the tonsure for a widow was a symbolic act in premodern Japan because it was not expected for a woman to sequester herself in convents after her husband's death. Widows occasionally resided in nunneries to devote their lives to praying for their deceased husbands, but they often continued to have sexual liaisons and enjoyed very public lives. Masako, for instance, remained heavily involved in political affairs after Yoritomo's death. She exiled her elder son, Yoriie 頼家 (1182-1204), for political incompetence and then appointed her eleven-year-old son, Sanetomo 実朝 (1192-1219), as the de facto ruler. ${ }^{15}$ Masako became the surrogate controller of the shogunate because Sanetomo was considered too young to effectively rule the military government.

Many women had economic motives for taking the tonsure because they received a widow's portion (gokebun 後家分) and controlled their son's property until he reached adulthood if they became nuns. Widows from this period were also prohibited from remarrying and were required to demonstrate full devotion to their husband in the afterlife or surrender their husband's property rights to his children. It is written in the Goseibai shikimoku (御成敗式目; $1232 \mathrm{CE}$ ), a legal code for the warrior government that "as long as a widow has received the husband's property, she should devote herself exclusively to praying for his afterlife. Should she quickly forget chastity and remarry, the deceased husband's bequest should pass to his children" (Tonomura 1990, p. 602). Buddhist embroideries incorporating a widow's hair like Masako's served as this symbolic gesture of chastity and fidelity, virtues essential for widows to maintain due to economic reasons.

The Chronical of Great Peace (Taiheiki 太平記) shows that widows used their own hair for embroidered images even when they had access to the hair of their husbands. ${ }^{16}$ Hino Toshimoto's 日野俊基 (?-1332) unnamed wife desperately waits for her husband's return while he is off to battle as the military advisor of Emperor Go Daigo 後醍醐天皇 (1288-1339). She discovers that her husband was captured and executed for plotting against the Kamakura regime when she receives a letter containing a lock of his hair. Although Hino Toshimoto's wife possessed the material remains of her husband, she dedicates an embroidered image that incorporates her own tonsured hair for his forty-ninth day memorial service, a crucial moment because it was believed on this date that the fate of the deceased was determined. ${ }^{17}$

\section{The Legends of Chūjōhime}

Hair embroideries can be interpreted as memento mori, a symbol of the inevitability of death, but also powerful embodied objects capable of transferring posthumous merit to the deceased. The meaning of Chüjōhime's hair-embroidered images, though, cannot be situated between the nexus of memorialization and chastity because she was believed to be unmarried and to have stitched these images herself prior to death. The earliest mention of Chūjōhime's hair embroideries also date much later than these examples, to the year 1492. ${ }^{18}$ Hair embroideries created by Chūjohime then challenge these normative narratives. It is impossible to speak of a singular Chüjōhime as images and texts concerning her life were adapted over time to meet the needs of new audiences. The name Chūjōhime, or Princess Chūjō, first appears in a late-twelfth-century document related to the making of the Taima mandara, the central image of worship at the temple of Taimadera 當麻寺. Scholars have not been able to identify the historical persona of Chūjōime, and most likely, she is a legendary figure who originated as a Japanese model for the Indian Queen Vaidehî (J. Idaike 韋提希) whose story of salvation is depicted on the left-hand register of the Taima mandara (Glassman 2004). ${ }^{19}$ Queen Vaidehī is imprisoned by her son, Prince Ajātaśaru (Ajase 阿闍世), for thwarting his plans to murder his father. The Śakyamuni Buddha sends two monks to Queen Vaidehī in prison who help her attain deliverance through sixteen meditations of Amida's Pure Land which include contemplating the jeweled trees of this Western Paradise and the body of the Amida Buddha. ${ }^{20}$ The tales of Chüjōime and Queen Vaidehī are similar in that both women attain rebirth by visualizing Amida's Pure Land and they both aim to transmit these revelations to others. 
The earliest images related to Chūjōhime, including the mid-thirteenth century Illustrated Story of the Miraculous Origin of the Taima mandara handscroll (Taima mandara engi emaki 當麻曼荼羅縁起絵巻), emphasize the possibility of even a woman achieving salvation through the contemplation of the Taima mandara (Figure 1). ${ }^{21}$ Accompanied by six pictorial sections, the text of this scroll explains that a young woman named Chūjōhime wished to envision the Amida Buddha in human form. As she meditates, Amida Buddha, disguised as a nun, appears to Chūjōhime and instructs her to gather one hundred loads of lotus stems, spin the fibers into threads, and dye these threads into the five Buddhist colors of blue, black, white, red, green, and yellow. Chūjōhime orders a group of conscripted laborers to complete these tasks, and subsequently, the bodhisattva Kannon 観音 (Ch. Guanyin Sk. Avalokiteśvara) appears disguised as a nun and weaves the dyed lotus threads together to create the Taima mandara tapestry overnight. The next morning, the two transfigured nuns reveal their identities as the Amida Buddha and the bodhisattva Kannon to Chüjōime and explain the significance of the Taima mandara's iconography. They claim that the mandara is a visual representation of the glories of Amida's Pure Land and preach that all beings, including women, can attain rebirth by visualizing its features. The handscroll concludes with an image of Chūjōime diligently contemplating the Taima mandara as Amida Buddha and a crowd of dancing bodhisattvas descend from the Pure Land to welcome her into the Buddha's paradise.

In the 15th century, authors, artists, and playwrights invent new legends surrounding Chūjōhime that serve as prequels to the earlier tale: fabricating a Cinderella-like life story of childhood abandonment and entangling her in illicit love affairs to highlight her moral virtue. Although the locations and timing of events differ in each storyline, the tales generally follow the same sequence. ${ }^{22}$ Chüjohime loses her mother at a young age and copes with a jealous stepmother. At age thirteen, she is accused of an illicit affair with a monk and brings chaos to her family. Due to this sexual transgression, Chūjōhime's family abandons her at Hibariyama 雲雀山 and orders a retainer to kill her at this mountain. The retainer takes pity on Chūjōhime, however, and raises her on Hibariyama with his wife. Chüjōhime eventually reunites with her father who urges her to return home, but she ultimately decides to take the tonsure at Taimadera and pray for the soul of her deceased mother in the hopes that they will reunite again in the Pure Land. The tale concludes with Amida Buddha appearing to Chūjōime after she takes the tonsure and orders her to create the Taima mandara to achieve this goal of uniting with her mother in the afterlife.

Another theme in these later tales is deep physical suffering brought on by the female body. In the Kabuki play, Abandoned Princess at the Pine Tree on Mt. Hibati (Hibariyama hime sutematsu 雲省山姫捨松; $1690 \mathrm{CE}$ ), for instance, Chūjōhime suffers from prolonged menstruation (shimo no yamai 下の病) as karmic punishments for her sexual transgressions with the monk (Tanaka 1996, pp. 53-56). It is also believed that Chūjōhime planted a cherry tree at Gangōji in Gifu Prefecture in honor of the bodhisattva Kannon who cured her of a venereal disease. This tree is thought to have salvific powers to heal other women suffering from similar conditions. Chūjōhime also lives on in the contemporary imagination in a medicine known as Chūjō's Hot Water (Chījōtō 中将湯), prescribed to alleviate menstrual difficulties (Burns 2009, pp. 179-202).

As Bernard Faure has noted, Chūjōhime is a rare "sexed bodhisattva" in a long Asian Buddhist tradition of sacred women as sexless beings (Faure 2003, pp. 198-201). Chūjōhime herself suffers from the physical ailments associated with the female body, but her suffering leads her to attaining enlightenment. People begin to inscribe the name of Chūjōhime on the backs of hair-embroidered Buddhist images at this moment in the late fifteenth century when her legends become increasingly humanized and popularized. It is also in this period that derogatory images of women associated with blood hell narratives became increasingly rampant. The body was the locus of women's entrapment, but it also became her tool of deliverance. Hair embroidered Buddhist images may have been seen as symbols of this dual nature that Chüjōime achieved between the sacred and the 
profane-embodied objects serving as visual and material markers for the ways the female body could simultaneously be enlightened and polluted.

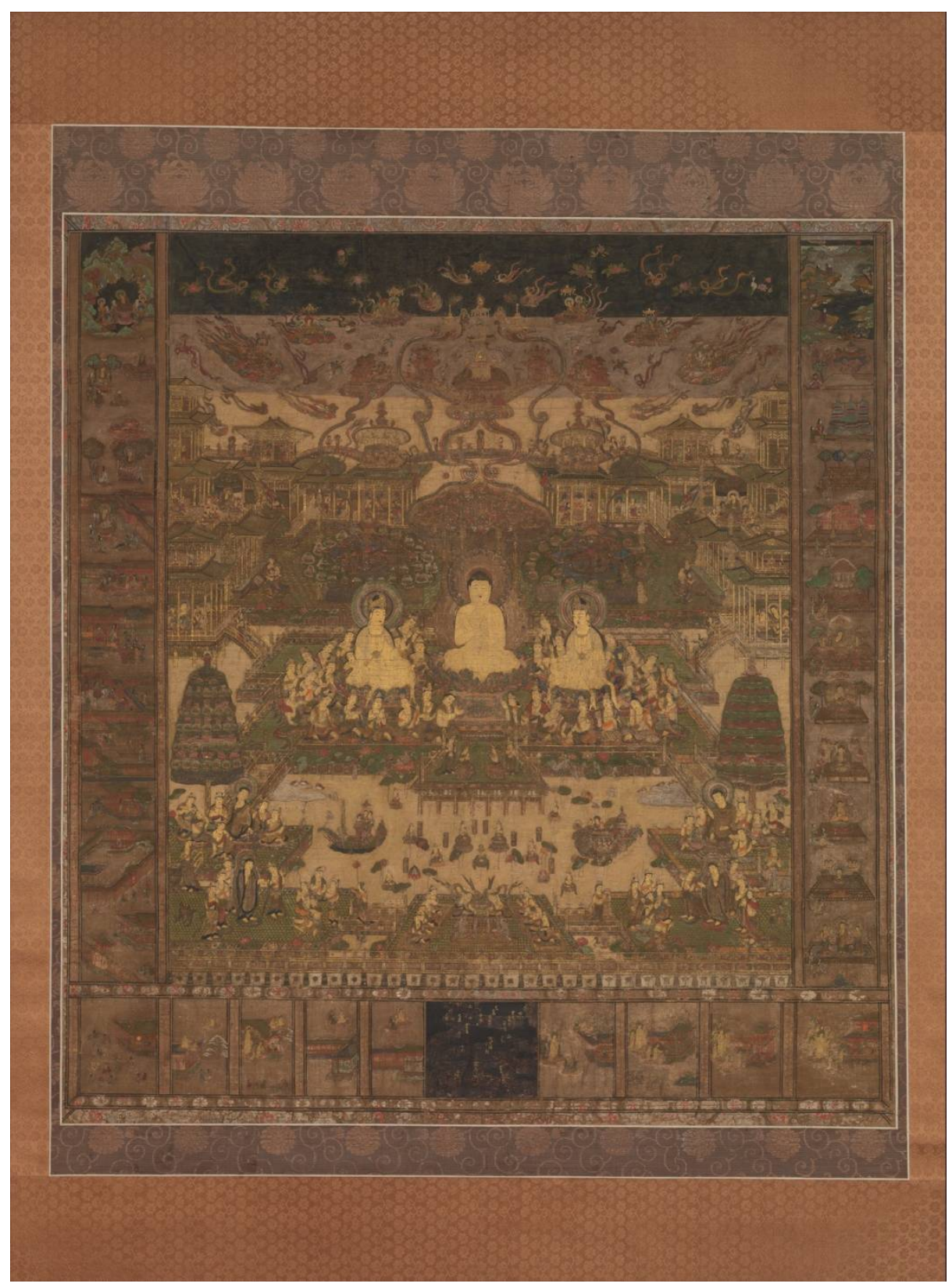

Figure 1. Taima mandala (mandara) (later reproduction), Late 14th century, Hanging Scroll; color and gold on silk, Height: $133.4 \mathrm{~cm}$, Width: $121.9 \mathrm{~cm}$, The Metropolitan Museum of Art (artwork in the public domain). Source: The Metropolitan Museum of Art, published under fair use.

\section{Chūjōhime's Hair Embroideries}

Hair embroidered Buddhist images attributed to Chūjōhime echo this celebration of female enlightenment in their visuality and materiality. The most prevalent images attributed to her are textiles of the Welcoming Descent of Amida Triad (Sanzon Amida raigōzu 三尊阿弥陀来迎図) depicting the Amida Buddha and his two attendants, Kannon and Seishi 勢至 (Sk. Mahāsthāmaprāpta), welcoming the deceased into the Western Pure Land (Figure 2). A nun, possibly meant to be Chūjōhime, is often represented in these textiles in the right-hand corner seated on a veranda awaiting her rebirth. Paintings and embroideries of the Welcoming Descent of the Amida Triad were used in memorial services as well as gyakushū services 逆修, a pre-mortem ritual said to be seven times 
more effective for securing an auspicious rebirth than those posthumously performed by relatives (Phillips 2003, pp. 120-45). This image became an independent Pure Land Buddhist painting genre with the popularity of The Essentials of Birth in the Pure Land (Ōjōyosh $\bar{u}$ 往生要集; 985), written by the Tendai Buddhist monk Genshin 源信 (942-1017), in which he explains the proper deathbed practices for a fortuitous rebirth (Sudō 1994, pp. 23-24). It was also intimately associated with Chūjōime because the iconography for this image can be traced back to the lower register of the Taima mandara which depicts the visualizations of the Contemplation Sutra (Figure 3).

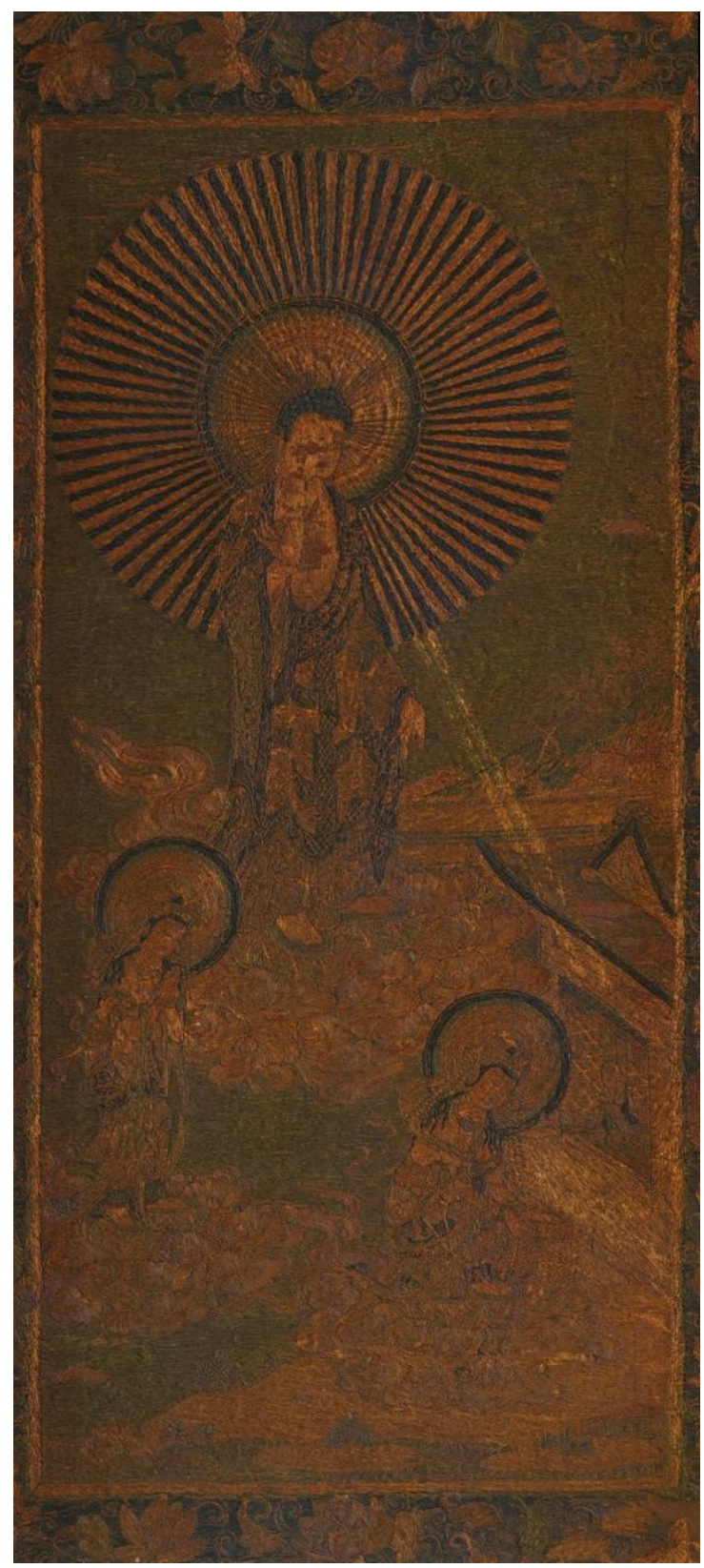

Figure 2. Descent of Amida Triad, 14th-15th century, Hair and silk thread embroidery on plain weave silk, Shōchi'in, Wakayama Prefecture, Height: $58.4 \mathrm{~cm}$, Width: $26.2 \mathrm{~cm}$. Source: Ito no mihotoke, Nara National Museum (Nara: Nara National Museum, 2018, 86). 


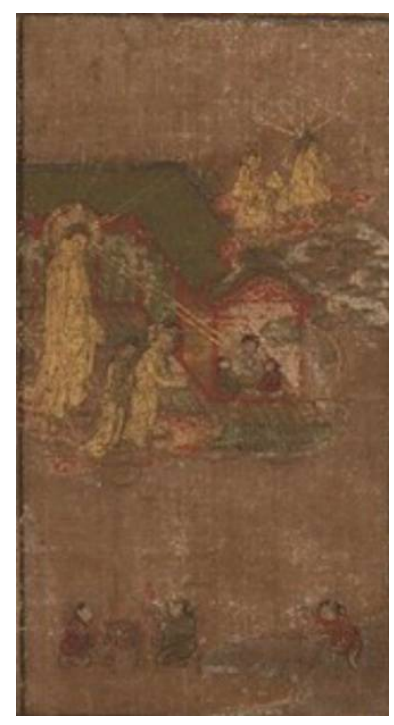

Figure 3. Taima mandara (mandala), detail of Figure 1 showing one of the nine possible degrees of rebirth, The Metropolitan Museum of Art (artwork in the public domain). Source: The Metropolitan Museum of Art, published under fair use.

This textile not only visually shows us the moment Chūjōhime achieves buddhahood (jōbutsu 成仏) but also articulates that message in its materiality. Hair is not used to represent the nun, possibly a portrait of Chūjōhime herself, but rather the hair, robes, and mandorla of the Amida Buddha, Kannon, and Seishi. The materiality of Amida Budha's mandorla, the largest object in the image, vacillates between golden-colored thread and human hair, simultaneously alluring and repulsive, both intimate and ceremonial. Using gold thread had religious significance and demonstrated more than its maker's affluence. It was believed that the Amida Buddha's body was golden and that the use of this color to ornament Buddhist images and sanctuaries could further activate the divine. Gold was also believed to counteract the polluting effects of death and the impurity of the body. For instance, the mummified body of Fujiwara no Kiyohira 藤原清衡 (1056-1128) at Chūsonji's 中尊寺 Golden Hall (kondō 金堂) was interred within a golden casket inside an altar adorned in gold (Sudō 1989, pp. 66-130; Yiengpruskawan 1993, pp. 33-52). The material of gold thread in this embroidery may have been perceived to have the capacity to purify the negative powers attributed to women's hair. As the hair of Chüjōhime achieves unity with the hair and emanating light of the Amida Buddha, these Welcoming Descent of Amida Triad embroideries enact women's longing to achieve salvation.

Sanskrit seed-syllable hair embroideries attributed to Chūjōhime, which reflect the important theme of women's rebirth to her tales and material culture, are also prevalent. The Sanskrit Seed-Syllable "A," in particular, was used in ajikan 阿字観 visualization practices (Payne 1998, pp. 219-48; Bogel 2009, pp. 199-200) (Figure 4). ${ }^{23}$ The "A" syllable, as the first letter of the Sanskrit alphabet represented the origin of all things and was believed to be the source of all sound. The Shingon Buddhist monk Kakuban 覚鋑 (10951143) argued that meditating on the Sanskrit Seed-Syllable "A" acquired soteriological benefits such as the achievement of rebirth into the Pure Land and oneness with Amida Buddha (Nakano 2010, pp. 184-86). The Sanskrit Seed-Syllable "A" was also written on the foreheads of believers who passed away from famines and earthquakes that befell the capital so they could attain rebirth (Nara National Museum 2018, p. 284). The thirteenthcentury monk, Mujū 無住 (1227-1312), in particular, wrote of the many soteriological benefits accrued by creating hair embroideries depicting Sanskrit seed-syllables (Zōtanshū 1950, p. 347). He argued that anyone could achieve enlightenment in this life (sokushin jōbutsu 即身成仏) and deliverance from transmigration (tokudatsu 得脱) by stitching their hair into these symbols. 


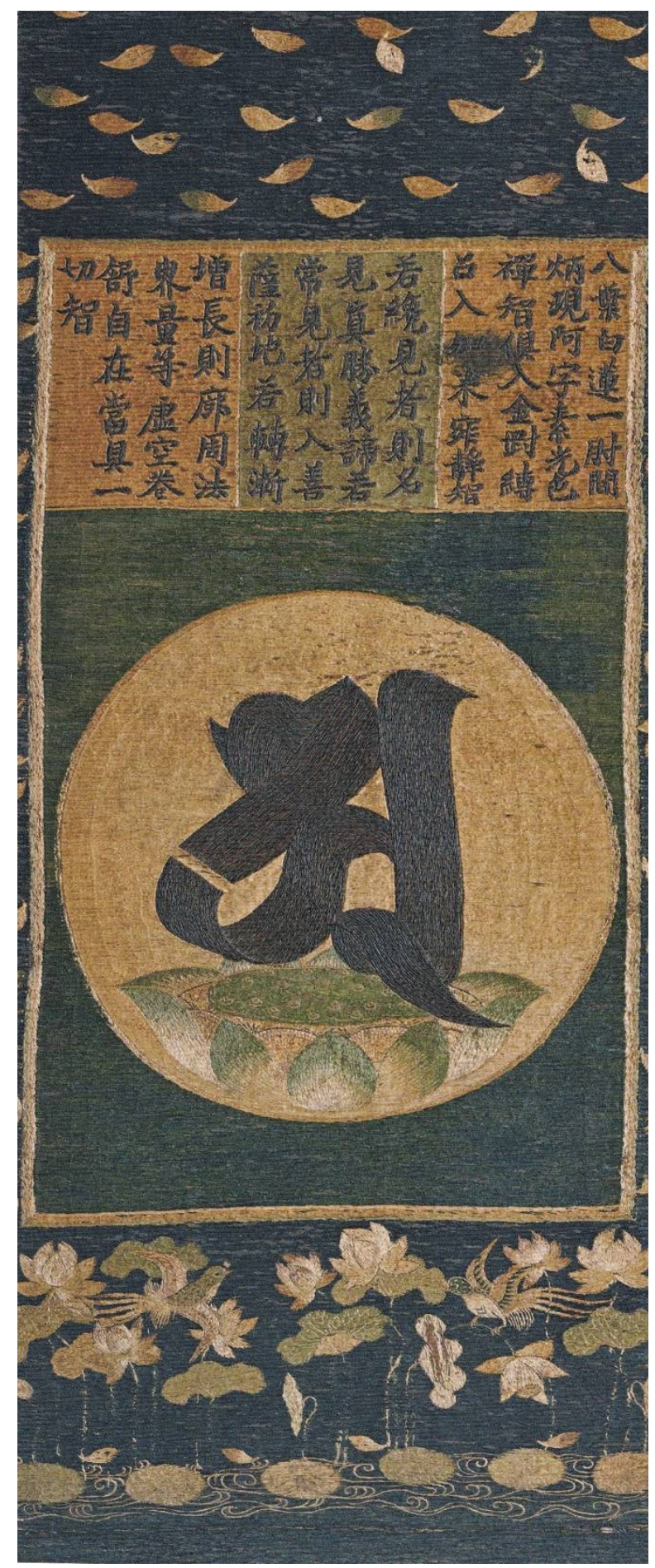

Figure 4. Sanskrit Seed-Syllable A, 14th century. Hair and silk thread embroidery on plain weave silk, Shōchi-in, Wakayama Prefecture, Height: $69.5 \mathrm{~cm}$, Width: $32.7 \mathrm{~cm}$. Source: Ito no mihotoke, Nara National Museum (Nara: Nara National Museum, 2018, 190).

Inscriptions on the back of these embroideries most commonly describe the materials used-such as Chūjōhime's hair and remnant lotus threads gathered and dyed for the making of the Taima mandara-suggesting that the materiality of these objects was central to its ritual efficacy. ${ }^{24}$ The inscription on a Sanskrit Seed-Syllable Amida Triad hair embroidery from Kombu-in 興福院, a Pure Land Buddhist convent in Nara, for instance, states that "Chūjōhime sewed this image with her own hands using hair from her own comb and remnant lotus threads from the [Taima] mandara." 25 Tim Ingold has taken seriously the 
agency embedded within the material composition of objects and writes, "things are alive and active not because they are possessed of spirit ... but because the substance to which they are comprised continue to be swept up in circulations of the surrounding media" (Ingold 2007, p. 12). These embroidered Buddhist images can be viewed as a "meshwork" into which human and nonhuman actors join together not as an "assemblage" but "a tangle of threads and pathways" (Ingold 2011, p. 64). This entangled relationship between "materials" and "believers" can be seen in wider Pure Land Buddhist ritual practices. For instance, there are records that state that devotees ingested lint fibers-referred to as “Taima Mandara jewels” (Taima mandara shu 當麻曼陀羅珠)—collected from a woven Taima mandara at the Pure Land Buddhist temple in Kyoto, Tenshōji 天性寺, as a method of attaining rebirth. ${ }^{26}$

The inscriptions on the back of these embroidered images also call attention to Chūjōhime's direct involvement in their production, indicating the central role of human agency in fashioning this web of dynamic substances. A Sanskrit Seed-Syllable Amida Triad from Taimadera, for instance, has an inscription which states that Chūjōime "used her own hair" and that "she herself stitched the image" (自髪自縫) emphasizing her labor and direct engagement with the object. ${ }^{27}$ According to Ingold, the agency of substances is processual and relational, joining forces with an active participant through the making, use, and deterioration of the thing (Ingold 2013, p. 21). He writes that materials "are neither objectively determined nor subjectively imagined but practically experienced. In that sense, every property is a condensed story. To describe the properties of materials is to tell the stories of what happens to them as they flow, mix, and mutate" (Ingold 2007, p. 14). Embroidered Buddhist images then can be interpreted as sites through which this material of polluted bodily matter can flow and mutate into sacred matter through the maker's processual act of stitching.

The discovery of Chūjōhime's hair embroideries across Japan today reveals that the circulation and exchange of these embodied objects were crucial for establishing her cult. ${ }^{28}$ The earliest record concerning Chūjōime's hair embroideries dates to 1492 and claims that 48 of these images were offered as gifts to pilgrims and prominent monks who visited Taimadera (Nara National Museum 2018, p. 274). Sutras said to be copied by Chūjōime were already widely collected by the fourteenth century. For instance, the Illustrated Biography of the Priest Ippen handscroll (Ippen Hijiri-e 一遍聖絵), created in 1299, claims that the itinerant monk, Ippen 一遍 (1234-1289), received a copy of the Sutra in Praise of the Pure Land (Shōsan jōdo kyō 称讃净土経) written by Chūjōhime after his pilgrimage to Taimadera, noting that he cherished the object throughout his life. ${ }^{29}$ An entry from 1492 in the Daily Records of the Honorable Lady of the Imperial Office of Housekeeping (Oyudono no ue no nikki 御湯殿上日記) indicates that even imperial female attendants acquired sutras thought to be copied by Chūjōime (Hioki 2010, pp. 327-30). Copies of The Sutra in Praise of the Pure Land thought to be written in Chūjōime's hand are crucial material objects to her story of rebirth because in some versions of these tales, Chūjōhime spends a full year making a thousand copies of this text until the Amida Buddha appears to her due to this devotional act. ${ }^{30}$ The existence of Chūjōime's cult, as we see, was irreducibly "thingly" (Hodder 2012, p. 38), yet what distinguishes the hair-embroidered images from the sutras attributed to her is that the former objects repurpose gendered material of long black hair into a devotional image offering an alternative approach to rebirth that focuses on the transformation of the body.

The most unusual finds attributed to Chūjōime are hair-embroidered Buddhist images of Dainichi Nyorai 大日如来 (Sk. Mahāvairocana) (Figure 5). Clasping the left index finger with the right hand, the Cosmic Buddha, Dainichi Nyorai, makes the gesture of the "Wisdom-Fist" mudra (chiken' in 智拳印), signaling a union between the spiritual and the material world (Saunders 1960, pp. 102-7). The lotus pedestal he sits upon seems to float atop a diamond-patterned gold ground, suggesting that this image, unlike the Welcoming Descent of Amida Triad, exists in an ethereal space outside the human realm. Dainichi Nyorai is never mentioned in tales related to Chūjōhime. Moreover, as the central deity of 
the Shingon school of Buddhism, his primary site of worship at Mt. Kōya was inaccessible to all women. Elaborate adornment of peonies and karakusa 唐草 arabesque vine patterns surround the image of Dainichi Nyorai enclosing the Buddha with ornamentation suitable for his dignified status. Pious adornment, referred to as shōgon 荘厳, was considered an essential method to sanctify Buddhist images and ritual spaces as a means to manifest the divine in this world. ${ }^{31}$ This adornment, though, creates a strange inverse relationship. The entire surface of this plain weave silk ground of the Dainichi Nyorai embroidery is covered in needlework, not a spot left untouched by what was believed to be Chūjōhime's hair and remnants of lotus threads. How can we reconcile this visual splendor that this image projects with the actual material of female hair? Why entangle women's hair with the form of a deity whose main site of veneration was off-limits to them?

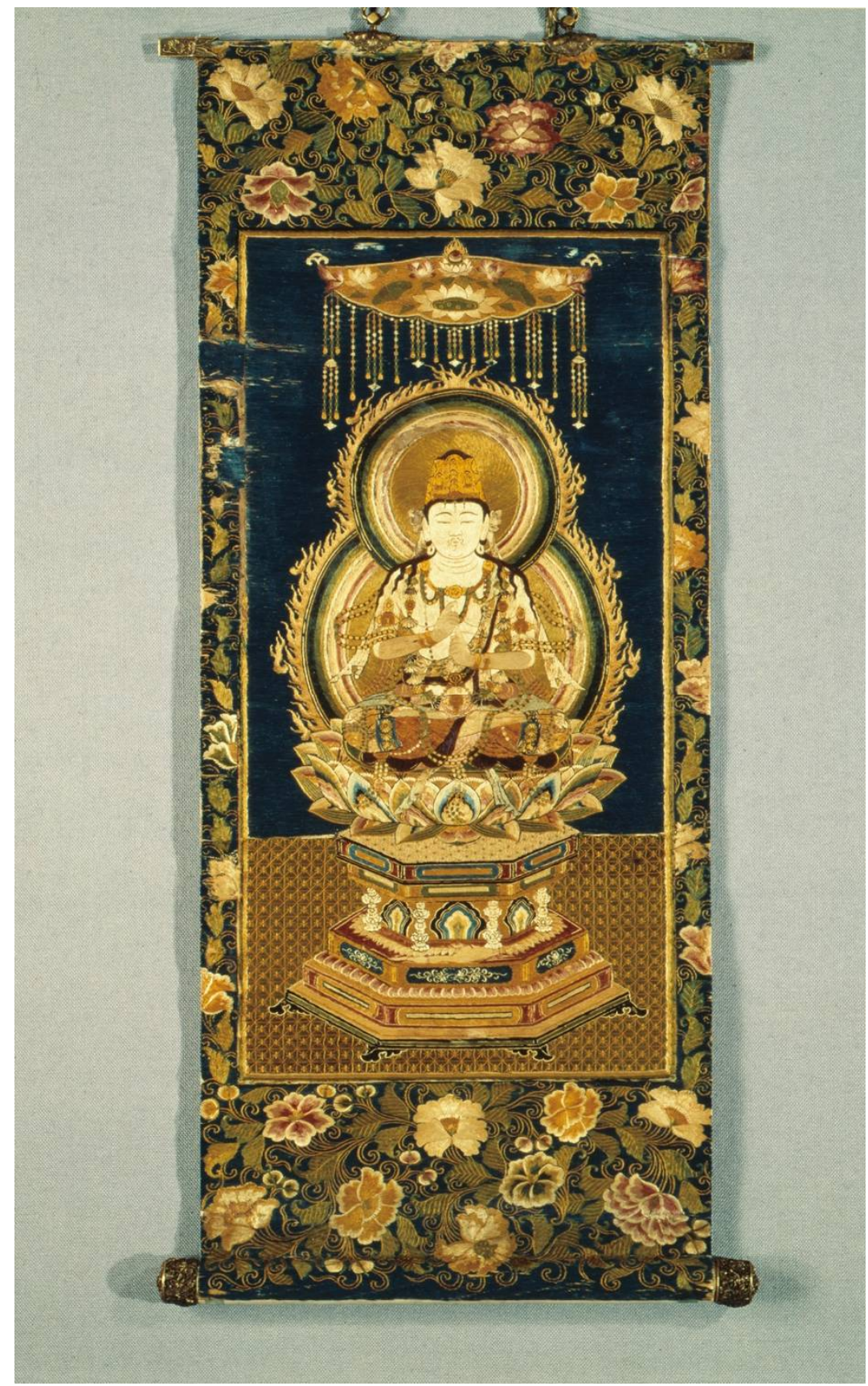

Figure 5. Dainichi nyorai, Kamakura Period (13th-14th century), Hair and silk thread embroidery on plain weave silk, Hosomi Museum, Kyoto Prefecture, Height: $41.2 \mathrm{~cm}$, Width: $25 \mathrm{~cm}$. Source: Hosomi Museum. 


\section{Embodied Images at Mt. Kōya}

Chūjōhime's hair embroideries also played a crucial role of establishing female corporeal presence in male-dominated spaces. Three hair-embroidered images attributed to her have been found at Shōchi'in 正智院 located on the top of Mt. Kōya, the headquarters of the Shingon school of Buddhism where women were prohibited from entering. These textiles depict the Welcoming Descent of Amida Triad, a Sanskrit Seed-Syllable " A", and a Six Letter Myōgō 名号 which refers to the phrase, "Namu Amida Butsu." This invocation was frequently chanted by Pure Land Buddhist believers to achieve rebirth in the Pure Land at the time of death. ${ }^{32}$ Two of these textiles were remounted at Shōchi'in during the 1650s and the 1660s at a moment when some tales of Chūjōime became instructive vehicles for the teaching of nonduality. ${ }^{33}$

In Chūjōhime in Her Original Form (Otogizōshi Chūjōhime no honji 御伽草子中将姫 の本地), for instance, monks reprimand Chūjōhime for entering the area of the main altar at Taimadera because she is a woman and order her to pray outside this space. Chūjōime refuses to concede. She recites the Vimalakitri Sutra on nonduality and claims that "before the Buddha, there is neither male nor female." 34 No storms emerge from the sky to punish Chūjohime. Nor does she turn into stone like the female figures who ignore the admonishments of monks to climb to the top of Mt. Kōya. The monks allow Chūjōimime to remain within the altar. A boulder with a footprint of Chūjōime can be found at Taimadera to this day, said to have been created by the noblewoman in anger when she was asked to leave the site because she is a woman (Jakushōdō kokkyōshū 1912, pp. 252-53).

Entangling female hair within Buddhist images placed at sites of nyōnin kekkai was not a new practice, especially at Mt. Kōya. The retired imperial consort, Bifukumon'in 美福門院 (1117-1160), was one of many historical women who questioned such limiting beliefs that she could not attain buddhahood by commissioning icons that incorporated her hair. Bifukumon'in became a fervent devotee of Mt. Kōya later in life, requesting male practitioners to make pilgrimages in her stead and sponsoring the construction of several temples on this sacred territory. In 1158, she commissioned two Buddhist statues, one for the Dainichi Hall and another for the Amida Hall, of Bodaishin-in 菩提心院 located on the mountain range (Lindsay 2012, p. 161). She inserted strands of her hair into these sculptures likely so that the material could serve as her proxy through which she could enter this prohibited site. The dedicatory text (kuyo ganmon 供養願文) written in conjunction with the patronage of these two images affirms Bifukumon'in's ardent desire to achieve enlightenment despite her polluted female body (Nishiguchi 1987).

"Every sentient being has the Buddha nature. How could women be left out? This place of Buddhist practice is itself the Dharma World. How can we call another place [the Land of] Utmost Bliss? I hope that this act of blessing at this time by all means will secure Awakening in the next world ... How can I not follow in the footsteps of the daughter of the Nāga King Sāgara? I will eradicate serious sins in order to seek the ninth level of rebirth in the Pure Land. I will revere the encompassing vows of the Buddha (Amida). The benefits of the Dharma world are limitless." 35

For premodern women, entangling their hair with images of the Buddha served a greater purpose than memorialization or activation. The icons, functioning as a medium of transference, aided women in achieving corporeal purity because their bodies were figuratively and literally merged with the divine. These embodied images function not unlike reliquaries by mediating viewers' experiences of the material of the female body. As Cynthia Hahn writes, reliquaries frame the relics with it as if "under pressure like a seltzer bottle ... as if the very act of containment increased power" (Hahn 2017, p. 58). Female hair is incorporated within Buddhist images not to conceal or shroud the material but to wrap and contain this corporeal substance within the visual form of a deity, thereby equating the power of this material with the power of what it represents, collapsing the 
sign with its referent. Women themselves may have not been able to enter sacred spaces like Mt. Kōya, but their agency could be mediated through these embodied objects. Alfred Gell has argued that "works of art, images, icons, and the like have to be treated in the context of an anthropological theory, as person-like: that is sources of, and targets for, social agency" (Gell 1998, p. 96). From this perspective, hair-embroidered images, embodying the sensations and desires of their female makers, can be considered powerful agents through which women enact their aim to practice a pious way of life and project their wishes to attain buddhahood.

\section{The Afterlives of Hair Embroidered Images}

The practice of Buddhist hair embroidery evolved into a communal project that engaged women and men of all socioeconomic classes from the imperial court, the monastic community, and commoners by the late seventeenth century. A monk named Kūnen 空念 from Daijuin 大樹院 in Fushimi, Kyoto, traveled throughout Japan from 1678 to 1692 and sewed sixty-nine large-scale hair embroideries for Pure Land Buddhist temples from northern Kyūshū to northeastern Japan (Hioki 2010, p. 293). While the first few embroidered images consisted of depictions of the Buddha's Nirvana (Nehanzu 涅槃図) and the Welcoming Descent of Amida and Twenty-Five Bodhisattvas embroideries (Nijūgo bosatsu raigōzu二十五菩薩来迎図), most of the later hair embroideries were representations of the Taima mandara. Unlike hair embroideries attributed to Chūjōhime which used a combination of both silk thread and hair, every stitch in Kūnen's embroideries incorporated human hair. Primarily using a simple backstitch technique, Kūnen differentiated between black and white hairs by using the latter for clouds and the silhouettes of the figures.

Creating monumental hair-embroidered images became a lucrative fundraising method for temples. An entry from the Okufuji monogatari 奥富士物語, a diary of events that occurred in Mutsu Province during the ruling of Tsugaru Nobumasa 津軽信政 (1646-1710), claims that in 1691, 128,004 people donated their hair to be incorporated into a Taima mandara embroidery that was $82 \mathrm{~cm}$ tall by $79 \mathrm{~cm}$ wide, at Sesshūin 搨取院in present-day Aomori Prefecture (Hioki 2010, p. 285). The number of contributors may be an exaggeration, but records retelling Kūnen's visits to Sesshūin confirm just how momentous this occasion was in the lives of rural believers. The village headman (shōya庄屋) of Goshogawara 五 所河原 described Kūnen's visit in the Hirayama nikki 平山日記, a record of the Hirayama family in the village that spans rom the mid-16th to the early 19th century.

八月朔日上り藤崎万日念仏堂二而旅僧参、曼荼羅継申候、此僧八上方上り行脚 之僧二候由、男女不寄老若、人之髮毛を集、其髮毛を集、其髮毛二而縫申㬋 間、是奇代之名人と申候。参詣之男女髮を报れながら難有と申候而銭 7 出、拝 又申候。

"From the First of August, a traveling monk from Kamigata (Kyoto region) visited [Sesshūin] to create a [Taima] mandara. Hair was collected from both men and women, both the young and the old, because Kunnen wanted to use hair as the material for [the embroidery]. People referred to Kūnen as a master of conspiring wonderful feats. I witnessed male and female visitors alike, in the midst of prayer, offering coins and thanks, as their hairs were drawn [from their heads]." ${ }^{36}$

Kūnen's hair-embroidered images also gained wide acclaim among feudal lords and the imperial court. The Okufuji monogatari includes an account of Tsugaru Nobumasa 津 軽信政 (1647-1710), the feudal lord of the Hirosaki Domain, contributing three strands of hair to be used to portray a portion of Amida Buddha's neck in Sesshūin's Taima mandara Hioki 2010, p. 284). In 1678, Emperor Go-Mizunoo visited Usa Hachimangū 宇佐八幡 in Ōita Prefecture to view one of Kūnen's completed Taima mandara hair-embroidered images (Hioki 2010, pp. 273-74). Kūnen preached that the merits of incorporating hair into Buddhist embroideries extended to include benefits for this life as well. The Sesshüin Hasshu Mandara no engi 摂取院髮紼曼陀羅之縁起, an origin story concerning the Sesshūin Taima mandara hair embroidery states, "according to this act [of donating hair], your father 
and mother who precede you will find themselves in the Pure Land and the children and descendants you leave behind will enjoy longevity." 37

The connection between this devotional practice and Chūjōhime remained unforgotten as Kūnen was celebrated as the reincarnated figure of Chüjōhime and was referred to as the "Second Coming of Chūjōhime Kannon" (Chūjōhime Kannon bosatsu sairai 中将姫観音 菩薩再来). However, the function of these hair embroideries essentially differed. Kūnen preached that paying tribute to a hair-embroidered Taima mandara acquired the same merit as conducting a pilgrimage to Taimadera, a teaching that must have appealed to rural commoners particularly in the Tōhoku region of Japan who could not make the arduous journey to visit the site where Chüjōime attained rebirth. This teaching also suggests that Kūnen's hair embroideries functioned as portable simulacra of the temple. Simulacra, according to Gilles Deleuze, cannot be considered a degraded copy but rather an image that "harbors a positive power which denies the original and the copy, the model and the reproduction" (Deleuze 1990, p. 262). The aim, then, with Kūnen's hair embroideries, was not the creation of a fixed imitation of the Taima mandara but an image that collapses time and space, a reproduction that merges the subject and the object, the visual form of Amida's Pure Land with the corporeal materiality of the human body.

Temples also displayed hair embroideries attributed to Chūjohime in rural areas in the form of traveling exhibitions (degaichō 出開帳). Literally meaning “opening of the curtains," kaichō entail the temporary unveiling of icons and significant paraphernalia to the public (Hur 2009). The Kaichō danwa 開帳談話 (1829 CE), an illustrated book by the ukiyo-e artist Kōriki Enkō'an 高力猿猴庵 (1756-1831), depicts a touring exhibition from Taimadera that was performed for five years throughout the countryside of Japan (Hayashi 1995, pp. 277-340) (Figure 6). Tanenobu's illustration shows men, women, and children walking through an exhibition at a temple in Nagano Prefecture, as nuns direct the visitors' attention to the many images on view including Chūjōhime's hair embroideries. Hank Glassman has noted that all the handlers of the art objects in these illustrations are nuns, which implies that only women had the privilege to display and explain works connected to Chūjōhime (Glassman 2004, pp. 154-57). Like the nuns proselytizing the Blood Bowl Sutra on the Kumano pilgrimage route, the discourse concerning Chūjōime's enlightenment passed from one woman to another, yet, the content of what these nuns preached differed. While the nuns of Kumano offered practical solutions for concerns in this life, such as rites of safe childbirth and talismans for eradicating menstrual pollution, Pure Land Buddhist nuns offered women solutions for the afterlife by displaying hair-embroidered images and explaining its content to audiences (Meeks 2020). Kumano bikuni claimed that women were bound to a polluted female body whereas nuns proselytizing Chūjōhime's teachings creatively worked within the constraints of teachings concerning nyōnin kekkai and used her hair-embroidered images as evidence that the female body could be transformed into a vessel of purity. 


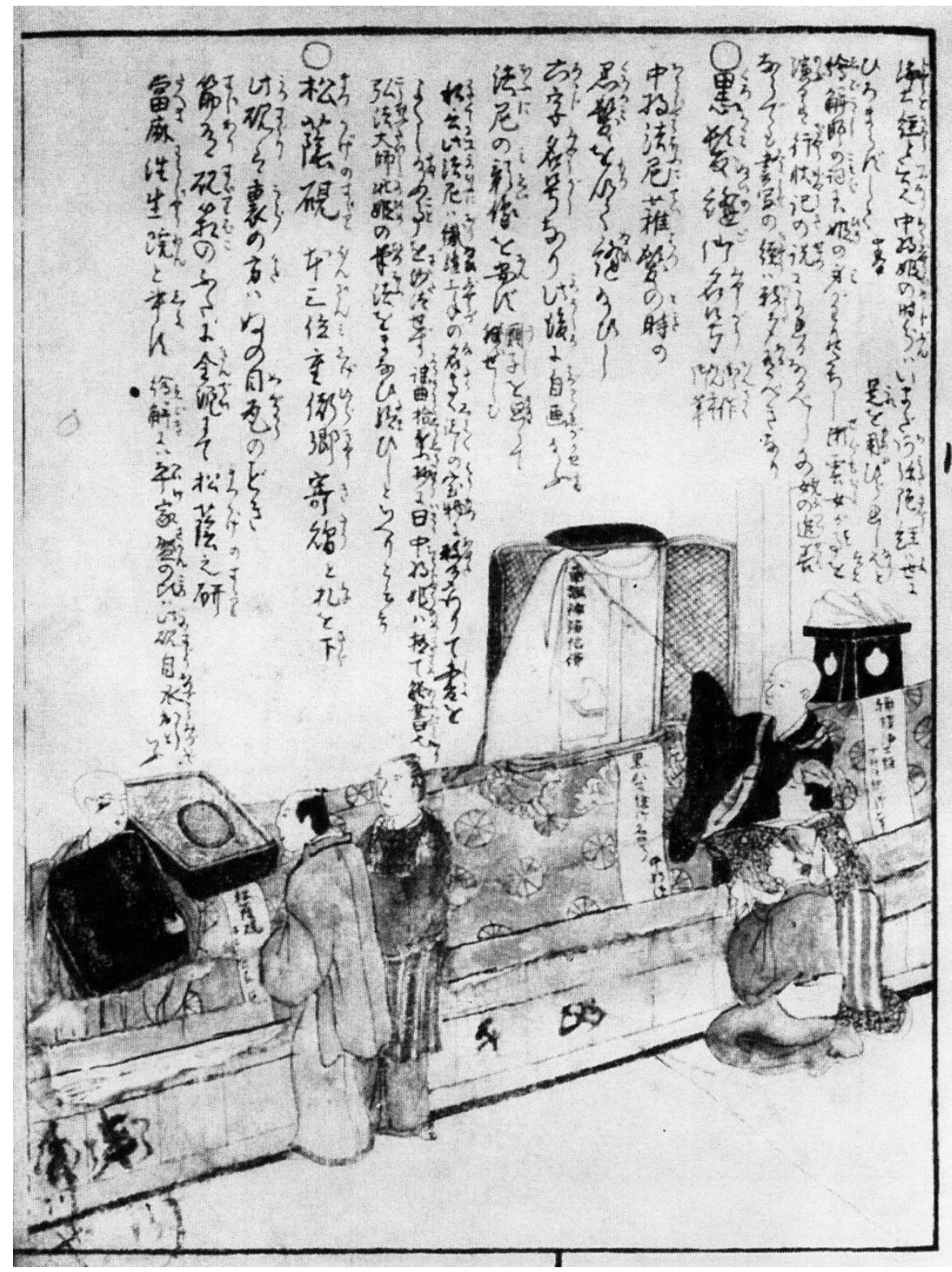

Figure 6. Chūjōhime's hair embroidery on display. From Saru-an Takariki Tanenobu (1756-1831), Kaichō danwa, 1829. Source: Hayashi Masahiko, Edo o itoite jōdo e mairan: Bukkyō bungakuron, (Tokyo: Meicho Shuppan, 1995, 315).

\section{Conclusions}

Scholars agree that women were active participants in religious communities, sponsoring ritual ceremonies and founding temples in premodern Japan. Tracing the material culture made for and by women also reveals the ways dominant modes of practice were adapted to meet the needs and desires of a female audience. Buddhist images embroidered with human hair are not simply objects of memorialization, gifts of exchange, relics of important figures, or an embodiment of the Taima mandara. These objects represent the desires of their makers to transform the female body into that which could embody the form of the Buddha. Hair embroideries give us an idea that beliefs concerning the polluted female body were contentious in premodern Japan at best; in some cases, the female body was celebrated, while in others it was an object of disgust. In particular, hair embroideries attributed to Chūjōhime were considered material evidence that women were capable of being reborn in Amida's Pure Land, despite the impurities of the female body. Venerating Chūjōhime's hair embroideries and donating one's hair to be incorporated within Buddhist 
images were likely just two of many devotional acts that developed in response to beliefs in blood impurity. Such acts began to permeate religious thinking during the late seventeenth century and gradually transformed conventional Pure Land Buddhist devotional practices into a more embodied experience. Hair embroideries interacted with the viewer in a sophisticated manner to show the interplay between the visuality and materiality of Buddhist icons. The visual splendor of these textiles may initially capture our attention, but it is the inanimate matter itself that whispers to us, alive with a vibrant and active force.

Funding: This research was funded, in part, by the Japan Foundation.

Conflicts of Interest: The author declares no conflict of interest.

\section{Notes}

1 At least sixteen versions of the Blood Bowl Sutra circulated in Japan. The blood pools described in Chinese and early Japanese versions of the Blood Bowl Sutra initially only contained parturitive blood. By the seventeenth century, however, menstrual blood was also added to this polluted category (Takemi 1983, pp. 236-39; Williams 2005, pp. 125-28; Meeks 2020).

2 The other three categores of agency exhibited by religious women in Burke's summary include "resistance agency" which is characterized by women's desires to modify practices, "empowerment agency" which enables women to feel emotionally empowered by their practices, and "instrumental agency" in which material benefits are accrued through religious devotion. According to Burke, these categories are distinct but not mutually exclusive. (Burke 2012).

3 The five obstructions are also invoked by Śāiputra (Sharihotsu 舎利弗) in the Lotus Sutra as he remains deeply skeptical of women's abilities to attain buddhahood due to their corporeal impurity (Moerman 2005, pp. 186-94).

4 The Blood Bowl Sutra was also used in Chinese Daoist practices and the earth god described here refers to a Daoist deity who later became popular in Japan (Yoshioka 1965, pp. 132-38).

5 Extant examples of the Kumano Heart Visualization and Ten World Mandala have fold lines which indicate that these paintings were not mounted like a hanging scroll but were carried along in traveling cases. These Kumana mandalas must have also been frequently used because most surviving examples are incredibly worn (Ruch 2002, pp. 566-75; Kaminishi 2006, pp. 137-63).

6 For an extensive iconographical analysis of the Kumano Heart Visualization and Ten World Mandala, see (Kuroda 2004, pp. 177-216).

7 This is an excerpt from an English translation of the Bussetsu Mokuren shōkyō ketsubon kyō 仏説目連正教血盆経, an undated woodblock printed version of a Blood Bowl Sutra discovered at Sōkenji 宗賢寺in Niigata Prefecture.

8 The Tale of Genji (Genji monogatari 源氏物語) provides accounts of many aristocratic women participating in activities like embroidery as a method of self-fashioning and gift-giving. Court women embroidered pictures of famous places (meisho-e 名所 絵) and lines from their favorite waka poems on their outermost garments to express their artistic sensibility and even gifted their textiles as mementos. The poetess Kenreimon'in 建礼門院 (1155-1213), for instance, embroidered her poems with purple floss onto a monk's surplice (kesa 袈乷) and offered the garment to the poet, Fujiwara no Shunzei 藤原俊成 (1114-1204) (Genji monogatari 1997; Kenreimon'in ukyō no daibu shū 2001).

9 There are frequent references to the long hair of aristocratic women in premodern Japanese poetry and literature such as the early eleventh-century Tale of Genji. Women's long thick hair was perceived as a sign of beauty, but it was also considered a material through which women's desires and internal thoughts could be communicated. Disheveled hair, in particular, is associated with the passionate and unruly desires of women. The poet, Izumi Shikibu 和泉式部 (970-1030), for instance, deescribes her longing for a past lover though her unkempt hair 「黒髮の乱れも知らずうち臥せば・まづかきやりし人ぞ恋しき」(Ebersole 1998, pp. 75-104; Pandey 2017, pp. 45-54).

「かの髮をもつて、梵字を縫ひて、供養の願文の奥に、わが涙かかれとてしもなでざりし子の黒髮を見るぞ悲しき」 (Shasekishū 1943).

11 The Masukagami uses the term 「遊義門院の御ぐしにて」 to describe how Emperor Go-Uda accumulated Yūgimon'in's hair. See (Masukagami 2007).

12 Known as tsuizen 追善, memorial services were performed not simply as events of commemoration but also as a place to transfer merit to the deceased by reciting prayers and bestowing precious offerings. Memorial services were performed at regular intervals every seventh day after a person's death which culminated in the grand forty-ninth day service. The ceremony was followed then by a hundredth-day service, a first annual memorial service ( $i k k a i k i$ 一回忌), and additional ceremonies continued to be performed each year on the anniversary of the individual's death. For a study on death rituals in medieval Japan, see (Gerhart 2009).

13 The Azuma kagami was written between 1268 and 1301 to record the Kamakura administration's policies and legitimize Hōjō rule. The text covers events from 1180 to 1266 and was compiled using a source of administrative documents, correspondences, reports, house records, diaries, and literary narratives. (Azuma kagami 1995). 
Masako's elder son, Yoriie, turned against his mother because he favored the advice of his wife's family, the Hiki 比訨 clan (Colcutt 1994).

16 This historical epic concerns Emperor Go-Daigo's reassertion to the throne through the demise of the Hōjo shoguns from 1319 to 1367. There are multiple versions of the Taiheiki. The story concerning Toshimoto's wife creating an embroidery is only featured in the Tenshō 天正 version (Taiheiki 太平記 1998).

17 On the significance of the forty-ninth day memorial service, see (Walter 2008, pp. 268-70).

18 The inscription on the back of the Welcoming Descent of Amida Triad embroidery from Shōchi'in's 正智院 claims that this image embroidered with Chūjōime's hair is one of forty-eight embroideries made by her (Nara National Museum 2018, p. 274).

19 Scholars have four theories concerning the historical model for Chüjōhime, yet none have been proven as factual. One theory holds that Chūjōhime refers to the daughter of the nobleman, Fujiwara no Toyonari 藤原豊成 (704-765), while another claims that she is the wife of Toyonari, named Momoyoshi百能 (720-782), who commissioned a sculpture of Amida Buddha for the benefit of her family at Kōfukuji. A third theory states that she is Taima no Yamashiro 當麻山背, the daughter of Taima Mahirō 當麻真人老 who later married Prince Toneri 舎人親王 (676-735) and gave birth to the future Emperor Junnin 淳仁天皇 (733-765). For the fourth theory, scholars argue that she is Akirakeiko 明子 (829-900), who married Emperor Montoku 文徳天皇 (826-858) and gave birth to Empero Seiwa 清和天皇 (850-878). Akirakeiko was a fervent supporter of Enchin円珍 (814-891), a Tendai Buddhist monk who traveled to China and received several Buddhist embroideries that were commissioned by Empress Wu Zeitan 武則天 (624-705). It has been suggested that Enchin brought back the Taima mandara to Japan and Akirakeiko may have introduced this tapestry to the Japanese court (Tanaka 1970; Ten Grotenhuis 1980, pp. 174-77).

20 The sixteen meditations can be divided into two categories. The first category called the Thirteen Meditations includes features of the Pure Land that one should meditate upon at the moment of rebirth: (1) the sun (2) water (3) the ground (4) jeweled trees (5) the pond (6) pavilions (7) Amida's Lotus Throne (8) the image of Amida Buddha (9) the body of Amida (10) the bodhisattva Kannon (11) the bodhisattva Seishi (12) the devotees achieving rebirth in the Pure Land and (13) smaller images of the Amida Buddha. The second category of the Sixteen Meditations includes a description of each of the three levels of rebirth. The Thirteen Meditations are depicted on the right panel while the levels of rebirth are illustrated in nine panels on the bottom register of the Taima mandara.

21 Texts from the Kamakura period that mention a female patron involved in the creation process of the Taima mandara are listed below in chronological order: Kenky ū gojunrei $k i$ 建久御巡礼記 1191, Taima mandara chūk $i$ 當麻曼荼羅注記 1223, Taimadera ryūk $i$ 当 麻寺流記 1231, Taimadera konryū no koto 當麻寺建立事 1237, Kokin mokurokushō 古今目録抄 1238, Yamatokuni Taimadera engi 大 和國當麻寺縁起 1253, Kokin chakumonshū 古今著聞集 1254, Shishu hyakuin ensh $\bar{u}$ 私聚百因緑集 1257, Wash $\bar{u}$ Taimadera gokuraku mandara engi 和州當麻寺極楽曼荼羅縁起 1262, Zokukyō kunshō 續教訓抄 1270, Tohazugatari とはずがたり 1290, Ippen hijirie 一編 聖絵 1299, and Genkō shakusho 元亨釈書 1322 (Ten Grotenhuis 1980, pp. 154-55).

22 These tales include the Chūjō hōnyo bikuni denki 中将法如比丘尼伝記 (1704), the Zenzen taiheiki 前 々太平記 (1715), and the Chüjōhime gyōjōki 中将姫行状記 (1730). (Tanaka 2004, pp. 87-92).

23 There are two iconographical types of A-syllable icons based on whether the image is associated with the Diamond World Mandala or the Womb World Mandala. For a Sanskrit Seed-Syllable A embroidery referring to the Diamond World mandala, both the lotus pedestal and the syllable are depicted within a moon disk whereas for the Womb World mandala, the lotus pedestal rests outside of the moon disk.

24 Lotus flowers are an emblem of purity in a Buddhist context because, just as the lotus rises from the mud of the pond, so too, it was believed, that the being who achieves buddhahood rises above the impurity of this world.

The inscription states「中将姫之御クシ之ケニテ御テッカラ御縫ヒ、蓮花其外八曼荼羅之系ニテ御ヌイ也」 (Ishida and Nishimura 1964, p. 67).

26 The setsuwa tale, Shincho monju 新著聞集 (1749 CE), and the Shinsen ōjoden 新撰往生层, a collection of biographies of people who attained rebirth in the Amida Buddha's Pure Land, discuss the practice of ingesting fibers from the image of the Taima mandara. The Mandarasan Tenshōji engi narabi hōmotsu raiyu 曼荼羅山天性寺縁起並宝物来由, a text concerning the origin of Tenshōji's treasures, claims that the temple had three large grains and thirty-seven small grains of fibers that were extracted from the Tenshōji Taima mandara tapestry and then stored within the temple to be given to believers (Gangōji Bunkazai Kenkyūjo 1983, p. 103).

27 The inscription here uses the verb to stitch nui 縫, rather than the verb to make saku 作 that is commonly found on Buddhist images. This term saku can and is also used to refer to a patron not directly involved in the physical creation process of the image. By using the term nui instead, this text highlights Chüjōhime's direct engagement with the object.

28 For a further discussion on the role of material culture in the spread of Chüjōhime's cult see (Sekiyama 1985).

29 Scroll Eight of the Illustrated Biography of the Priest Ippen handscroll discusses Ippen's visit to Taimadera (Komatsu 1981, pp. 223-26).

30 In Chūjōhime's tales from the seventeenth century onwards, such as the Taima byakki 当麻白記 (written in 1614 and published in 1648), the Mirror for Women of Our Land (Honchō jokan 本朝女鑑; 1661 CE), a compilation of female biographies for the edification of women, and the Earlier Pre-Taiheiki (Zenzen taiheiki 前 々 太平記; 1715 CE), a tale concerning the events of the Nara-period court, 
Chūjōhime devotes herself to writing a thousand copies of the Sutra in Praise of the Pure Land (Shōsan jōdo kyō 称讃浄土経) for a full year before she encounters the Amida Buddha (Tanaka 2004, pp. 87-92).

Shōgon is a Japanese Buddhist term that can be translated into English as "pious adornment" and can be grouped into three types: (1) splendid things that adorn the Image Hall (2) splendid things that adorn the Buddha's body and (3) virtues and good deeds with which Buddhas and bodhisattvas adorn themselves. The term originates from the Chinese word zhuangyan and combines two Ancient Indian concepts: alamkara meaning to "manifest the divine" and vyuha which means to "make perfect." For a discussion on the soteriological benefits of shōgon, see (Mochizuki bukkyō daijiten 1958). For sources concerning ritual practices related to the nenbutsu, see (Stone 2004, pp. 77-119).

33 An inscription on Shōchi'in's Sanskrit Seed-Syllable A hair embroidery attributed to Chūjōhime, claims that this image had to be repaired and remounted in 1658. Shōchi'in owns another myōōo hair embroidery attributed to Chūjōime that was also remounted by the same craftsmen (hyōgushi 表具師) five years later in 1663.

The doctrine of nonduality in the Vimalakirti Sutra (Yuimakyō 維摩経) describes this non-binary identity and claims that there is neither an absolute male nor absolute female identity. For a brief English translation and further discussion on this text, see (Kimbrough 2008, p. 195; Chūjōhime no honji 2002).

35 English translation of the Prayers for the dedication of Bodaishin'in Temple (Bodaishi'in kuyō ganmon 菩提心院供養願文) (Lindsay 2012, pp. 163-64).

$36 \quad$ English translation by author.

37 The English translation comes from the following sentence, “此因縁によりて先立父母は浄土に往生し、残し子孫は寿命長生な ら".

\section{References}

\section{Primary Sources}

Genji monogatari 源氏物語. 1993. Shin Nihon koten bungaku taikei 新日本古典文学大系. Tokyo: Iwanami shoten, vol. 19.

\section{Secondary Sources}

Abé, Ryūichi. 2015. Revisiting the Dragon Princess: Her Role in Medieval Engi Stories and Their Implications in Reading the Lotus Sutra. Japanese Journal of Religious Studies 42: 27-70. [CrossRef]

Ambros, Barbara. 2008. Emplacing a Pilgrimage: The Oyama Cult and Regional Religion in Early Modern Japan. Cambridge: Harvard University Press.

Ambros, Barbara. 2015. Women in Japanese Religions. New York: New York University Press.

Azuma kagami 吾妻鏡. 1995. Kokushi taikei 国史大系. Tokyo: Yoshikawa kōbunkan.

Benn, James A. 2007. Burning for the Buddha: Self-Immolation in Chinese Buddhism. Honolulu: University of Hawai'i Press.

Bogel, Cynthea. 2009. With a Single Glance: Buddhist Icon and Early Mikkyō Vision. Seattle: University of Washington Press.

Brinker, Helmut. 2011. Secrets of the Sacred: Empowering Buddhist Images in Clear, in Code, and in Cache. Seattle: Spencer Museum of Art.

Burke, Kelsy C. 2012. Women's Agency in Gender-Traditional Religions: A Review of Four Approaches. Sociology Compass 6: 122-33. [CrossRef]

Burns, Susan L. 2009. Marketing Health and Beauty: Advertising, Medicine, and the Modern Body in Meiji-Taisho Japan. In East Asian Visual Culture from the Treaty Ports to World War II. Edited by Hans Thomsen and Jennifer Purtle. Chicago: Paragon Books, pp. 173-96.

Chūjōhime no honji 中将姫本地. 2002. Shinpen Nihon koten bungaku zenshü 新編日本文学. Tokyo: Shōgakukan.

Colcutt, Martin. 1994. Religion in the Formation of the Kamakura Bakufu: As Seen through the 'Azuma kagami'. Japan Review 5: 55-86.

Deleuze, Gilles. 1990. The Logic of Sense. Edited by Constantin V. Bounda. Translated by Mark Lester. New York: Columbia University Press.

Ebersole, Gary L. 1998. 'Long Black Hair Like a Seat Cushion': Hair Symbolism in Japanese Popular Religion. In Hair: Its Power and Meaning in Asian Cultures. Edited by Alf Hiltebeitel and Barbara D. Miller. Albany: State University of New York Press, pp. 75-104.

Faure, Bernard. 2003. The Power of Denial. Princeton: Princeton University Press.

Gangōji Bunkazai Kenkyūjo 元興寺文化財研究所. 1983. Chūjōhime setsuwa no chōsa kenkyū hōkokusho 中将姫説話の調査研究報告書. Nara: Gangōji Bunkazai Kenkyūjo.

Gell, Alfred. 1998. Art and Agency: An Anthropological Theory. Oxford: New York: Clarendon Press.

Gerhart, Karen. 2009. The Material Culture of Death in Medieval Japan. Honolulu: University of Hawai'i Press.

Gerhart, Karen, ed. 2018. Women, Rites, and Ritual Objects in Premodern Japan. Leiden: Brill.

Glassman, Hank. 2004. 'Show Me the Place Where My Mother Is!' Chūjōhime, Preaching, and Relics in Late Medieval and Early Modern Japan. In Approaching the Land of Bliss: Religious Praxis in the Cult of Amitäbha. Edited by Richard K. Payne and Kenneth K. Tanaka. Honolulu: University of Hawai'i Press, pp. 139-60.

Hagiwara, Tatsuo 萩原龍夫. 1983. Miko to bukkyōshi: Kumano bikuni no shimei to tenkai 巫女と仏教史：熊野比丘尼の使命と展開. Tokyo: Yoshikawa kōbunkan. 
Hahn, Cynthia. 2017. The Reliquary Effect: Enshrining the Sacred Object. London: Reaktion Books Ltd.

Hayashi, Masahiko 林雅彦. 1995. Edo o itoite, jōdo e mairamu: Bukkyō bungaku ron 穢土を厭ひて浄土へ参らむ：仏教文学論. Tokyo: Meicho shuppan.

Hioki, Atsuko 日沖敦子. 2010. Taima mandara to Chūjōhime 当麻曼荼羅と中将姫. Tokyo: Bensei shuppan.

Hirasawa, Caroline. 2013. Hell-Bent for Heaven in Tateyama Mandara: Painting and Religious Practice at a Japanese Mountain. Leiden and Boston: Brill.

Hodder, Ian. 2012. Entangled: An Archaeology of the Relationships between Humans and Things. Malden: Wiley-Blackwell.

Hur, Nam-Lin. 2009. Invitation to the Secret Buddha of Zenkōji Kaichō and Religious Culture in Early Modern Japan. Japanese Journal of Religious Studies 36: 45-63. [CrossRef]

Ingold, Tim. 2007. Materials against Materiality. Archaeological Dialogues 14: 1-16. [CrossRef]

Ingold, Tim. 2011. Being Alive: Essays on Movement, Knowledge, and Description. London: Routledge.

Ingold, Tim. 2013. Making: Anthropology, Archaeology, Art and Architecture. Hoboken: Taylor and Francis.

Ishida, Mosaku 石田茂作, and Hyōbu Nishimura 西村兵部. 1964. Shūbutsu 紼佛. Tokyo: Kadokawa.

Itō, Shinji 伊藤信二. 2012. Chūsei shūbutsu no 'shōgon yōshiki' ni tsuite 中世紼仏の「荘厳様式」について. In Yōshikiron: Sutairu to mōdo no bunseki 様式論：スタイルとモードの分析. Edited by Hayashi On. Tokyo: Chikurinsha, pp. 390-407.

Jakushōdō kokkyōshū: Jakushōdō kokkyō zokushū 寂照堂谷響集：寂照堂谷響續集. 1912. Dai Nihon bukkyō zensho 大日本文教全書. By Unshō (1614-1693). Tokyo: Bussho kankokai, vol. 149.

Kamens, Edward. 1993. Dragon-Girl, Maidenflower, Buddha: The Transformation of a Waka Topos, 'The Five Obstructions'. Harvard Journal of Asiatic Studies 53: 389-442. [CrossRef]

Kaminishi, Ikumi. 2006. Explaining Pictures: Buddhist Propaganda and Etoki Storytelling in Japan. Honolulu: University of Hawai'i Press.

Kanda, Fusae. 2005. Behind the Sensationalism: Images of a Decaying Corpse in Japanese Buddhist Art. The Art Bulletin 87: 24-49. [CrossRef]

Kenreimon'in ukyō no daibu shū 建礼門院右京大夫集. 2001. Shikishi Naishinnō shū, Kenreimon'in ukyō no daibu shū, Toshinari-kyō no Musume $s h \bar{u}, E n s h i$ 式子内親王集・建礼門院右京大夫集・俊成卿女集・艶詞. Waka Bungaku taikei vol. 23. Tokyo: Meiji Shoin.

Kimbrough, Keller. 2008. Preachers, Poets, Women, and the Way: Izumi Shikibu and the Buddhist Literature of Medieval Japan. Ann Arbor: University of Michigan.

Komatsu, Shigemi 小松茂美. 1981. Ippen Shōnin eden一遍上人絵层. Tokyo: Chūō Kōronsha.

Kuroda, Hideo 黒田日出男. 2004. Kaiga shiryō de rekishi o yomu 絵画史料で歴史を読む. Tokyo: Chikuma shobō.

Lindsay, Ethan Claude. 2012. Pilgrimage to the Sacred Traces of Kōyasan: Place and Devotion in late Heian Japan. Ph.D. thesis, Princeton University, Princeton, NJ, USA.

Mahmood, Saba. 2004. Politics of Piety: The Islamic Revival and the Feminist Subject. Princeton: Princeton University Press.

Masukagami 増鏡. 2007. Kokushi taikei 国史大系. Tokyo: Yoshikawa kōbunkan, vol. 21.

Meeks, Lori. 2010. Hokkeji and the Reemergence of Female Monastic Orders in Premodern Japan. Honolulu: University of Hawai'i Press.

Meeks, Lori. 2020. Women and Buddhism in East Asian History: The Case of the Blood Bowl Sutra, Part II: Japan. Religion Compass 14: 1-16. [CrossRef]

Mochizuki bukkyō daijiten 望月仏教大辞典. 1958. Edited by Mochizuki Shinkō 望月信亨. Tokyo: Sekai Seiten kankō kyōkai.

Moerman, Max D. 2005. Localizing Paradise: Kumano Pilgrimage and the Religious Landscape of Premodern Japan. Cambridge: Harvard University Press.

Nakano, Genzō 中野立三. 2010. Raigōzu ronsō: “raigōzu no bijutsu” sairon 来迎困論争 • 「来迎図の美術」再論. In Hōhō to shiteno bukkyō bunkashi: Hito mono imēji no rekishigaku 方法としての仏教文化史：ヒト・モノ・イメージの歴史学. Edited by Nakano Genzō, Kasuya Makoto and Kamikawa Michio. Tokyo: Benseishuppan.

Nara National Museum 奈良国立博物館. 2018. Ito no mihotoke: Kokuhō tuzureori Taima mandara to shūbutsu: Shūri kansei kinen tokubetsuten 糸のみほとけ：国宝綴織當麻曼余羅と紼仏：修理完成記念特別展. Nara: Nara National Museum.

Nishiguchi, Junko 西口順子. 1987. Onna no Chikara: Kodai no Josei to Bukkyō 女の力：古代の女性と仏教. Tokyo: Heibonsha.

Ohnuma, Reiko. 1998. The Gift of the Body and the Gift of the Dharma. History of Religions 37: 323-59. [CrossRef]

Pandey, Rajyashree. 2017. Perfumed Sleeves and Tangled Hair: Body, Woman, and Desire in Medieval Japanese Narratives. Honolulu: University of Hawai'i Press.

Payne, Richard K. 1998. Ajikan: Ritual and Meditation in the Shingon Tradition. In Re-Visioning "Kamakura" Buddhism. Edited by Richard K. Payne. Honolulu: University of Hawai'i, pp. 219-48.

Phillips, Quitman E. 2003. Narrating the Salvation of the Elite: The Jōfukuji Paintings of the Ten Kings. Ars Orientalis 33: 120-45.

Pradel, Chari. 2016. Fabricating the Tenjukoku Shūchō mandara and Prince Shōtoku's Afterlives. Leiden: Brill.

Ruch, Barbara. 2002. Woman to Woman: Kumano bikuni Proselytizers in Medieval and Early Modern Japan. In Engendering Faith: Women and Buddhism in Premodern Japan. Edited by Barbara Ruch. Ann Arbor: University of Michigan, pp. 537-80.

Saunders, Ernest Dale. 1960. Müdra: A Study of Symbolic Gestures in Japanese Buddhist Sculpture. Princeton: Princeton University Press.

Sekiyama, Kazuo. 1985. Chūjōhime densetsu to Taima mandara. In Etoki. Edited by Etoki no kenkyū-kai. Tokyo: Yūseidō, pp. 127-33.

Sharf, Robert H. 2011. The Buddha's Finger Bones at Famensi and the Art of Chinese Esoteric Buddhism. The Art Bulletin 93: 38-59. [CrossRef]

Shasekishū 沙石集. 1943. Iwanami bunko 岩波文庫. Tokyo: Iwanami shoten, vols. 1-2. 
Stone, Jacqueline Ilyse. 2004. By the Power of One's Last Nenbutsu: Deathbed Practices in Early Medieval Japan. In Approaching the Land of Bliss: Religious Praxis in the Cult of Amitābha. Edited by Richard Karl Payne and Kenneth Ken'ichi Tanaka. Honolulu: University of Hawai'i Press, pp. 77-119.

Sudō, Hirotoshi 須藤弘敏. 1989. Chūsonji konjikidō 中尊寺金色堂. In Chūsonji to Mōtsūji 中尊寺と毛越寺. Edited by Sudō Hirotoshi and Iwasa Mitsuharu. Osaka: Hoikusha, pp. 66-130.

Sudō, Hirotoshi 須藤弘敏. 1994. Kōyasan Amida shōju raigōzu: Yume miru chikara 高野山阿弥陀聖衆来迎図：夢見る力. Tokyo: Heibonsha.

Taiheiki 太平記. 1998. Shinpen Nihon koten bungaku zenshū 新編日本古典文学全集. Tokyo: Shōgakukan.

Takemi, Momoko. 1983. 'Menstruation Sutra' Belief in Japan. Japanese Journal of Religious Studies 10: 229-46. [CrossRef]

Tanaka, Hisao 田中日佐夫. 1970. Chūjōhime densetsu o horu 中将姫质説を掘る. Geijutsu Shinchō芸術新潮 3: 120-27.

Tanaka, Takako 田中貴子. 1996. Seinaru onna: Saigū, megami, Chūjōhime 聖なる女：斎宮・女神・中将姫. Tokyo: Jinbun shoin.

Tanaka, Mie 田中美絵. 2004. Chūjōhime setsuwa no kinsei: Kangebon ‘Chūjōhime gyōjōki' o jikuni 中将姫説話の近世・勧化本「中将 姫行状記」を軸に. Denshō bungaku kenkyū 53: 87-92.

Ten Grotenhuis, Elizabeth. 1980. The Revival of the Taima Mandala in Medieval Japan. Ph.D. thesis, Harvard University, Cambridge, MA, USA.

Ten Grotenhuis, Elizabeth. 2011. Collapsing the Distinction between Buddha and Believer: Human Hair in Japanese Esotericizing Embroideries. In Esoteric Buddhism and the Tantras in East Asia. Edited by Charles Orzech and Richard Payne. Leiden and Boston: Brill, pp. 876-92.

Tonomura, Hitomi. 1990. Women and Inheritance in Japan's Early Warrior Society. Comparative Studies in Society and History 32: 592-623. [CrossRef]

Walter, Mariko Namba. 2008. The Structure of Japanese Buddhist Funerals. In Death and the Afterlife in Japanese Buddhism. Edited by Jacqueline I. Stone and Mariko Namba Walter. Honolulu: University of Hawai'i Press, pp. 247-92.

Williams, Duncan Ryūken. 2005. The Other Side of Zen: A Social History of Sōtō Zen Buddhism in Tokugawa Japan. Princeton: Princeton University Press.

Yiengpruskawan, Mimi Hall. 1993. The House of Gold: Fujiwara Kiyohira's Konjikidō. Monumenta Nipponica 48: 33-52. [CrossRef]

Yoshida, Kazuhiko. 2002. The Enlightenment of the Dragon King's Daughter in the Lotus Sutra. In Engendering Faith: Women and Buddhism in Premodern Japan. Edited by Barbara Ruch. Translated by Margaret H. Childs. Ann Arbor: Center for Japanese Studies, University of Michigan, pp. 297-324.

Yoshioka, Yoshitoyo 吉岡義豊. 1965. Dōkyō kenkyú 道教研究. Tokyo: Shōshinsha.

Zōtansh $\bar{u}$ 雑談集. 1950. Koten bunko 古典文庫. Tokyo: Koten bunko, vol. 42. 